\title{
Mitogen-Induced Changes in Sialyltransferase Activity in Human Normal and Leukemic Lymphocytes
}

\author{
Ryuhei Sasaki, Fumimaro TAKaKu* and Yasusada Miura*
}

\begin{abstract}
Phytohemagglutinin-P (PHA-P) and concanavalin A (Con A) induced an increase in sialyltransferase (S-T) activity of the blood lymphocytes within 24 hours. PHA-P induced the maximal increase in S-T activity in the lymphocytes at $10 \mu \mathrm{g} / \mathrm{ml}$ and with Con $\mathbf{A}$ at $5 \mu \mathrm{g} / \mathrm{ml}$. PHA-P induced a greater response than that by Con A. An additional effect of these mitogens was not observed. The exposure of cell extracts to these mitogens did not induce the increase in S-T activity. PHA-P or Con A had no effect on the induction of terminal deoxynucleotidyl transferase (TdT) activity, TdT-positive cells or peanut agglutinin (PNA)-positive cells from blood lymphocytes. Therefore, the change of the lymphocytes induced by these mitogens does not indicate a reversion to more immature state of lymphocyte differentiation, but represents a process of the functional differentiation to more activated lymphocytes. These mitogens had only a slight effect on S-T activity of human T-lymphoid leukemia cell lines. The decreased effects of the mitogens on S-T activity of leukemic cells may reflect the change of the membranes due to malignant transformation or the incomplete membrane structure in undifferentiated leukemic cells.
\end{abstract}

Key Words: - Terminal deoxynucleotidyl transferas (TdT), Peanut agglutinin, PhytohemagglutininP (PHA-P), Concanavalin A (Con A), Sialyltransferase, Leukemia cell line

Sialyltransferase (S-T) is an enzyme that catalyzes the transfer of sialic acid to the terminal oligosaccharide residues of the glycoproteins or the glycolipids of membranes ${ }^{1)}$. S-T activity has been repeatedly assayed in the serum or on the surface of the cells derived from patients with malignancies. However, there are only a few reports on S-T activity in hemopoietic cells ${ }^{2-5}$. In this study we compared the effects of phytohemagglutinin-P (PHA-P) and concanavalin A (Con A) on S-T activity in normal human lymphocytes with those on the enzyme activity in human T-lymphoid leukemia cell lines.

\section{MATERIALS AND METHODS}

\section{Chemicals}

Phytohemagglutinin-P (PHA-P) and con- canavalin A (Con A) were purchased from Difco Labs. and Miles Labs., respectively. Desialylated fetuin was made according to the method of Kim et al. ${ }^{6}$ The same preparation of desialylated fetuin was used for the enzyme assay throughout this study. CMP- ${ }^{3} \mathrm{H}-\mathrm{NANA}$ (cytidine $5^{\prime}$ monophosphate- ${ }^{3} \mathrm{H}$-sialic acid, $\left.18.9 \mathrm{Ci} / \mathrm{mmol}\right)$ and ${ }^{3} \mathrm{H}$-dGTP $\quad\left({ }^{3} \mathrm{H}\right.$-deoxyguanosine $5^{\prime}$ triphosphate, $15 \mathrm{Ci} / \mathrm{mmol}$ ) were obtained from New England Nuclear, Boston, Mass. $\mathrm{F}\left(\mathrm{ab}^{\prime}\right)_{2}$ rabbit anti-terminal transferase, FITC-labelled goat antirabbit IgG, $\mathrm{F}(\mathrm{ab})_{2}$ and $\mathrm{p}(\mathrm{dA})_{\overline{50}}$ were the generous gifts from Dr. Bollum ${ }^{7}$.

\section{Cell culture}

Fresh blood cells from normal volunteers were separated with Ficoll-Hypaque solution. Nucleated cells in the intermediate layer (lympho-

From Department of Hematology, Jichi Medical School, Tochigi, Japan.

*The Third Department of Internal Medicine, Faculty of Medicine, University of Tokyo, Tokyo, Japan. Received for publication August 15, 1985.

Reprint request to: Ryuhei Sasaki, MD, 3311-1 Yakushiji Minamikawachi-Machi, Kawachi-Gun, Tochigi 329-04, Japan. 
cytes: $86-95 \%)$ were used for this study. Lymphoid leukemia cell lines (CEM, MOLT-3 and TALL) originating from T-ALL (T-derived acute lymphoblastic leukemia) were maintained in RPMI-1640 medium containing $10 \%$ inactivated foetal calf serum. Lymphocytes were cultured at $5 \times 10^{5}$ cells $/ \mathrm{ml}$ with PHA-P $(5 \mu \mathrm{g} / \mathrm{ml}-20 \mu \mathrm{g} / \mathrm{ml})$ or with Con A $(1 \mu \mathrm{g} / \mathrm{ml}-10 \mu \mathrm{g} / \mathrm{ml})$ in a humidified atmosphere of $5 \% \mathrm{CO}_{2}$ in air for 24 to 48 hours, then used for the enzyme assay. The viability of cultured cells (ranging from 82 to $94 \%$ ) were determined by trypan blue dye exclusion. The protein contents were determined according to the method of Lowry et al. ${ }^{8)}$ The presence of TdT-positive cells was surveyed as described previously ${ }^{9)}$. The detection of peanut agglutinin (PNA)-positive cells was done according to the method reported by London et al. ${ }^{10)}$

Assay of sialyltransferase (S-T) activity

The assay of S-T activity was essentially done according to the method reported previously ${ }^{5)}$. In brief, cells were suspended in $25 \mathrm{mM}$ Tris $\cdot \mathrm{HCl}$ buffer ( $\mathrm{pH}$ 7.2) containing $0.1 \%$ Triton X-100 and $1 \mathrm{mM}$ dithiothreitol, subjected to freezing and thawing, then centrifuged at $12,000 \mathrm{x} g$ for $15 \mathrm{~min}$. The reaction mixture contained $50 \mathrm{mM}$ Tris $\cdot \mathrm{HCl}$ (pH 7.2) $10 \mathrm{mM} \mathrm{MgCl} 2,6 \mathrm{mg} / \mathrm{ml}$ of desialylated fetuin, $0.2 \mathrm{mM}$ of $\mathrm{CMP}^{-}{ }^{3} \mathrm{H}-\mathrm{NANA}$. Apparent $\mathrm{Km}$ values of CMP-NANA and of desialylated fetuin were $63 \mu \mathrm{M}$ and $1.1 \mathrm{mg} / \mathrm{ml}$, respectively. Incubations were done at $37^{\circ} \mathrm{C}$ for $60 \mathrm{~min}$ by adding cell extracts, terminated with cold $0.5 \mathrm{~N} \mathrm{HCl}$ containing $1 \%$ phosphotungstic acid. Acid-insoluble products were washed with cold $5 \%$ trichloroacetic acid three times, then washed with ethanol-ether. The pellets were dissolved in $0.5 \mathrm{ml}$ of Soluene 350 (Packard), transferred to $10 \mathrm{ml}$ of Dimilume-30 (Packard) and counted in Aloca LSC-653 liquid scintillation spectrometer with counting efficiency of $56.9 \pm 4.1 \%$. The activity from endogenous reaction was subtracted from the activity obtained with desialylated fetuin. Enzyme activities were expressed as CMP- ${ }^{3} \mathrm{H}-\mathrm{NANA}$ incorporated per cells or per $\mathrm{mg}$ protein for $60 \mathrm{~min}$ at $37^{\circ} \mathrm{C}$. Reactions proceeded linearly until $90 \mathrm{~min}$. Increase in enzyme activity was linear when the cell extract obtained from $1 \times 10^{6}-8 \times 10^{6}$ cells was used.
Optimal conditions for $\mathrm{pH}$ of the buffers, for the concentrations of Triton X-100, metal ions ad others were used for this assay.

Assay of terminal deoxynucleotidyl transferase (TdT) activity

The assay of TdT activity was carried out, as described previously ${ }^{11,12)}$. $\mathrm{P}(\mathrm{dA})_{\overline{50}}(0.02 \mathrm{mM})$ was a primer. ${ }^{3} \mathrm{H}$-dGTP $(1 \mathrm{mM})$ was used as a substrate. Reactions were done at $35^{\circ} \mathrm{C}$ for 30 min. Endogenous radioactivity (no primer) was subtracted from the activity of $\mathrm{P}(\mathrm{dA})_{\overline{50}}$ primed reaction. One unit of the enzyme activity represents one $n$ mole of ${ }^{3} \mathrm{H}$-dGMP incorporated into $\mathrm{P}(\mathrm{dA})_{\overline{50}}$ for $30 \mathrm{~min}$ at $35^{\circ} \mathrm{C}$. In view of the findings of immunofluorescent analysis on TdTpositive cells, the cell suspensions with levels of activity less than 2.5 units per $10^{8}$ nucleated cells, were regarded as TdT-negative $\mathrm{e}^{11,12)}$.

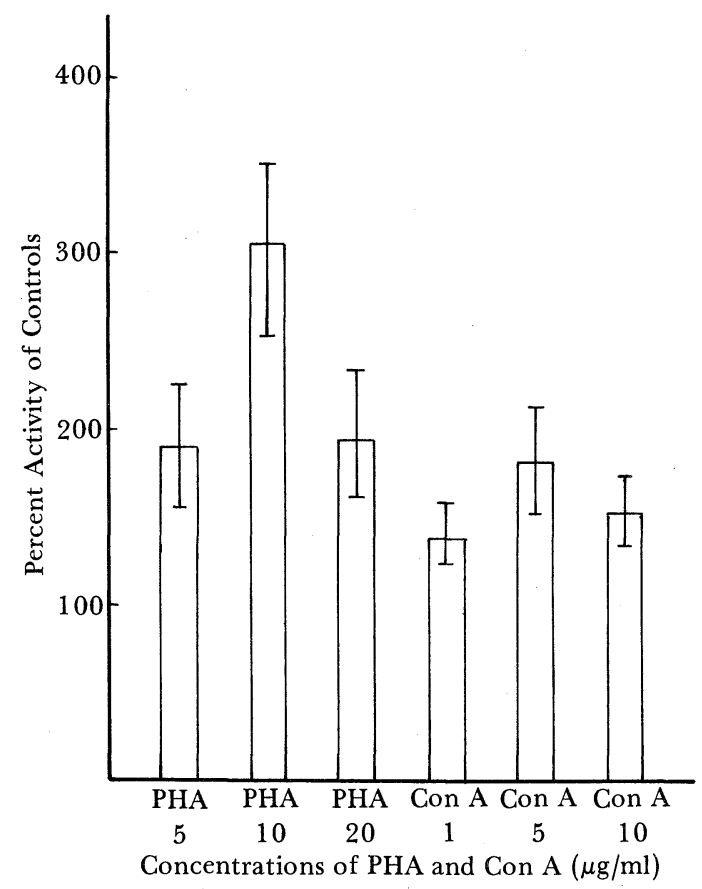

Fig. 1. Effect of PHA-P and Con A on S-T activity in the lymphocytes from normal volunteers in 24 hours culture. The level of S-T activity was calculated as ${ }^{3} \mathrm{H}$ CMP-NANA incorporated per cells, represented as percent of the average of controls. S-T activity of controls was $21.83 \pm 3.71 \mathrm{p}$ moles $/ 5 \times 10^{7}$ cells $/ 37^{\circ} \mathrm{C}$, $60 \min (n=7)$. 


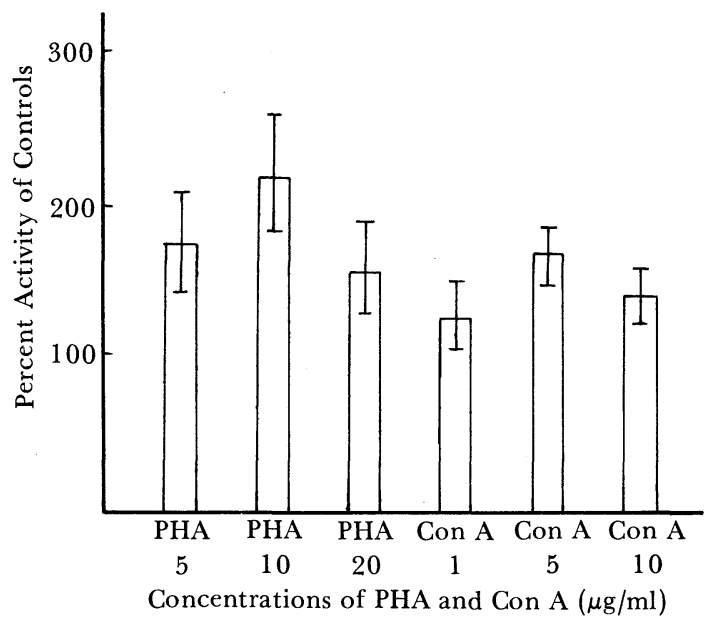

Fig. 2. Effect of PHA-P and Con A on S-T activity of the lymphocytes from normal volunteers in 24 hours culture. The level of S-T activity was calculated as ${ }^{3} \mathrm{H}$ CMP-NANA incorporated per mg protein, represented as percent of the average of controls. S-T activity of controls was $9.56 \pm 1.17 \mathrm{p}$ moles $/ \mathrm{mg}$ protein $/ 37^{\circ} \mathrm{C}$, $60 \min (n=7)$.

\section{RESULTS}

As shown in Figure 1, PHA-P induced maximal increase (approximately three times of controls) in S-T activity at $10 \mu \mathrm{g} / \mathrm{ml}$, while Con A induced maximal increase (approximately 1.8 times of controls) in S-T activity at $5 \mu \mathrm{g} / \mathrm{ml}$ in lymphocytes from normal volunteers. Similar results (Fig. 2) were noted, when the enzyme activities were expressed per $\mathrm{mg}$ protein of the cell extracts. However, no additional increase was noted using a combination of PHA-P $(10 \mu \mathrm{g} / \mathrm{ml})$ and Con A (5 $\mu \mathrm{g} / \mathrm{ml}$ ) (data not shown). The exposure of the cell extracts from normal lymphocytes with PHA-P or Con A did not induce any increase in S-T activity in vitro (Fig. 3). Therefore, the presence of viable cells is necessary for the increased S-T activity by these mitogens. Furthermore, PHA-P or Con A failed to induce TdT activity in the lymphocytes from the normal volunteers [Control: $0.31 \pm 0.06$ units $/ 1 \times 10^{8}$; PHA-P $(10 \mu \mathrm{g} / \mathrm{ml}): 0.16 \pm 0.02$ units $/ 1 \times 10^{8}$; Con A $(5 \mu \mathrm{g} / \mathrm{ml}): 0.13 \pm 0.01$ units $\left./ 1 \times 10^{8}\right]$. Similarly, the addition of these mitogens had no induction of TdT-positive cells or PNA-positive cells from blood lymphocytes.

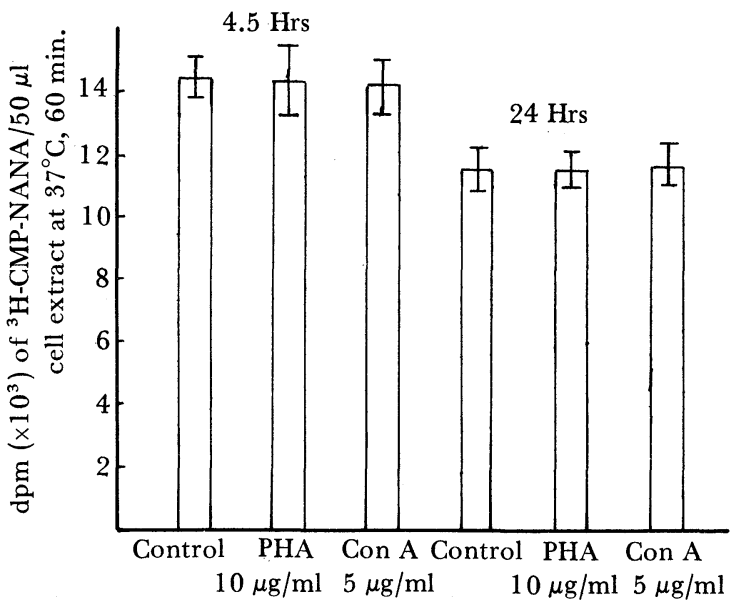

Fig. 3. Effect of PHA-P and Con A on the cell extracts in the lymphocytes from normal volunteers. The cell extracts were incubated with PHA-P $(10 \mu \mathrm{g} / \mathrm{ml})$ or Con A $(5 \mu \mathrm{g} / \mathrm{ml})$ for 4.5 hours or 24 hours, then $\mathrm{S}-\mathrm{T}$ activity was assayed.

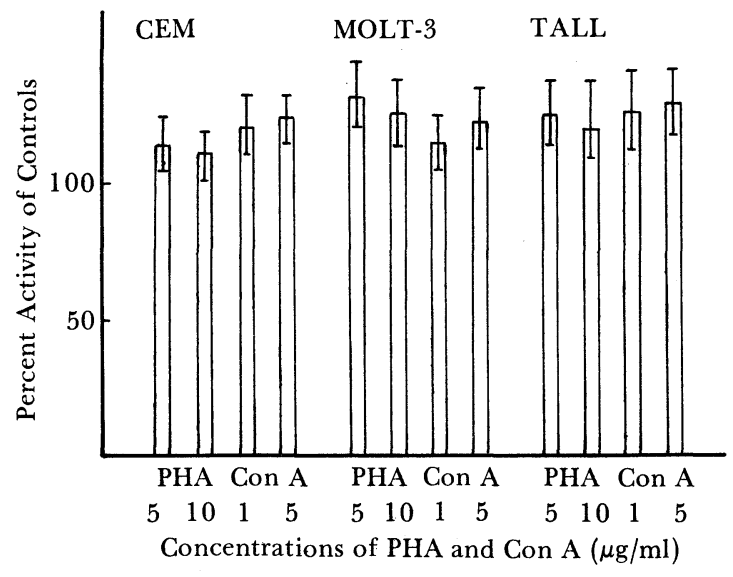

Fig. 4. Effect of PHA-P and Con A on S-T activity of lymphoid cell lines in 24 hours culture. The level of the enzyme activity was represented as percent of controls. S-T activities of controls in CEM, MOLT-3 and TALL cell lines were $8.18 \pm 1.32,5.36 \pm 0.75$, $7.48 \pm 1.20 \mathrm{p}$ moles $/ 5 \times 10^{7}$ cells, respectively.

The lymphoblasts in human T-lymphoid leukemia cell lines (CEM, MOLT-3 and TALL) exhibited significantly lower levels of S-T activity compared to that of normal mature lymphocytes. In addition, PHA-P and Con A had only a slight effect on S-T activity in these lymphoid leukemia cell lines, as compared to the effect on S-T activity in the lymphocytes from normal volunteers (Fig. 
4). Even after two-day culture, the mitogens had only negligible effects on S-T activity of CEM and MOLT-3 cell lines, similar to those observed after 24 hours incubation (data not shown).

\section{DISCUSSION}

Changes in membrane structure have been speculated to be involved in the process of the cell differentiation or of the malignant transformation $^{13,14)}$. Sialyltransferase is an enzyme that induces structural changes by transferring sialic acids to glycoproteins or glycolipids of the membranes. Therefore, it is conceivable that the quantitative or qualitative changes in this enzyme occur in the process of the differentiation ${ }^{15)}$ or the malignant transformation of the cells ${ }^{16)}$. Weiser showed that the immature, undifferentiated cells of intestinal epithelium have less sialic acid and decreased S-T activities, as compared to the mature cells ${ }^{17)}$. Furthermore, Despont et al. reported that the level of S-T activity was significantly lower in immature lymphoid cells (cortical thymocytes of mice) than that of more mature lymphoid cells such as medullary thymocytes and lymphocytes from the blood of mice ${ }^{2)}$. Previously, we found that the lymphocytes from the blood of normal volunteers contained significantly higher level of S-T activity than that of lymphoblasts from acute lymphoblastic leukemia cases ${ }^{5)}$. Also in this study, S-T activity of three lymphoid leukemia cell lines (CEM, MOLT-3 and TALL) was consistently lower than that of normal mature lymphocytes. Therefore, these results suggest that the level of S-T activity increases in the process of the differentiation of lymphocytes. However, we found the marked increase in S-T activity in lymphocytes from the blood of normal volunteers by PHA-P and Con A. This finding seems to be contradictory to the former concept, if the process of blast transformation by mitogens is considered as the reversion (differentiation) of mature lymphocytes to more immature cells. However, prior to the morphological change a marked increase in mitogen-induced S-T activity was observed. In addition, the incubation of the lymphocytes with the mitogens had no induction of TdT activity, TdT-positive cells or PNA-positive cells. It is well-known that lymphoid progenitor cells such as prothymocytes, cortical thymocytes and leukemic lymphoblasts are TdT-positive, PNApositive. Therefore, our results support the concept that the change in lymphocytes induced by PHA or Con A does not indicate a reversion of the lymphocytes to more immature stage of $\mathrm{T}$ cell differentiation, but represents a process of the functional differentiation to more activated lymphocytes. Significant increase in S-T activity by these mitogens may reflect one of the biochemical changes involved in the process of functional differentiation of the lymphocytes.

In human leukemic lymphoid cell lines, these mitogens showed little or no effect on S-T activity during 24 to 48 hours incubation. Probably, the change in the membrane structure due to malignant transformation or the incomplete membrane structure in undifferentiated leukemic lymphoblasts may be responsible for the minimal effect of these mitogens on S-T activity in leukemic cell lines.

ACKNOWLEDGEMENTS: The authors greatly appreciate Dr. I. Kubonishi, Kochi Medical School who kindly provided us lymphoid leukemia cell lines. We also express our great thanks to Miss T. Kumakura for the technical assistance. This work was supported by a grant for cancer research from the Ministry of Health and Welfare of Japan.

\section{REFERENCES}

1) Shur BD, Roth S: Cell surface glycosyltransferase. Biochim Biophys Acta 415: 473, 1975.

2) Despont JP, Abel CA, Grey HM: Sialic acids and sialyltransferases in murine lymphoid cells. Indicators of $\mathrm{T}$ cell maturation. Cell Immunol 17: 487, 1975.

3) Kessel D, Chou TH, Allen J: Some properties of sialyltransferase in plasma and lymphocytes of patients with chronic lymphocytic leukemia. Eur J Biochem 82: 535, 1978.

4) Steimer F, Despont JP: Cell surface changes in human normal and abnormal lymphoid cells detected by sialic acid content and sialyltransferase activity. Leukemia Res 4: 265, 1980.

5) Sasaki R, Takaku F, Lin Y-L, et al: Sialyltransferase activity as a marker for the differentiation of lymphocytes. Increase in sialyltransferase activity of blasts from acute lymphoblastic leukaemia cases by 12-0-tetradecanoylphorbol-13-acetate (TPA). Clin Exp Immunol 47: 381, 1982.

6) Kim YS, Perdomo J, Norberg J: Glycoprotein bio- 
synthesis in small intestinal mucosa. J Biol Chem 246: 5466, 1971.

7) Gregoire $\mathrm{KE}$, Goldschneider I, Barton RW, et al: Intracellular distribution of terminal deoxynucleotidyl transferase in rat bone marrow and thymus. Proc Natl Acad Sci 74: 3993, 1977.

8) Lowry $\mathrm{OH}$, Rosebrough NJ, Farr AL, et al: Protein measurement with the Folin phenol reagent. J Biol Chem 193: 265, 1951.

9) Sasaki R, Bollum FJ, Goldschneider I: Transient populations of terminal transferase $\left(\mathrm{TdT}^{+}\right)$cells in juvenile rats and mice. J Immunol 125: 2501, 1980.

10) London J, Perrot JY, Berrih S, et al: Peanut agglutinin. IV. A tool for studying human mononuclear cell differentiation. Scand J Immunol 9: $451,1979$.

11) Sasaki R, Takaku F, Bollum JF, et al: Detection of high TdT activity in bone marrow sera of leukemia cases. N Engl J Med 304: 1108, 1981.

12) Dan S, Sasaki R, Takaku F: An improved assay for terminal deoxynucleotidyl transferase (TdT) activity. Acta Haematol Jpn 44: 1131, 1981.

13) Berlin RD, Oliver JM, Ukena TE, et al: The cell surface. N Engl J Med 292: 515, 1975.

14) Edelman GM: Surface modulation in cell recognition and cell growth. Science 192: 218, 1976.

15) Madappally MM, Wislson JR, Zimmerman EF: Sialyltransferase in fetal tissues: Incorporation of sialic acid into endogenous and exogenous glycoprotein acceptors. Archiv Biochem Biophys 173: 1, 1976.

16) Ingraham $\mathrm{HA}$, Alhadeff $\mathrm{JA}$ : Characterization of sialyltransferase in non-cancerous and neoplastic human liver tissue. J Natl Cancer Inst 61: 1371, 1978.

17) Weiser MM: Intestinal epithelial cell surface membrane glycoprotein synthesis. J Biol Chem 248: 2542, 1973.

18) Greaves M, Janossy: Patterns of gene expression and the cellular origins of human leukemias. Biochem Biophys Acta 516: 193, 1978. 